\title{
Implementing Cost-effective Co-treatment of Domestic and Food-industrial Wastewater by Novel Methods for Estimating Industrial Load
}

\author{
Vince Bakos ${ }^{1 \star}$, Péter Szombathy ${ }^{1}$, József Simon¹, Andrea Jobbágy \\ 1 Department of Applied Biotechnology and Food Science, Faculty of Chemical Technology and Biotechnology, \\ Budapest University of Technology and Economics, H-1111 Budapest, Műegyetem rkp. 3., Hungary \\ * Corresponding author, e-mail: vbakos@mail.bme.hu
}

Received: 19 November 2019, Accepted: 05 February 2020, Published online: 09 July 2020

\begin{abstract}
Detection and characterization of hidden industrial inflows causing high fluctuations of the inlet load, is a challenging issue pushing plant operators for a cost-effective solution at regional wastewater treatment plants (WWTPs). On the other hand, carbon source of food industrial origin may have a good use at WWTPs facing otherwise inlet carbon source deficiency.

In a case study of a regional domestic WWTP receiving seasonally organic carbon-rich discharge from a fruit juice factory, a new method combining on-site measurements and mathematical modelling was developed and successfully applied for estimating the quality and quantity of both industrial influent load and incoming domestic wastewater streams properly. The originally un-staged bioreactor system operated at low dissolved oxygen (low DO) concentration was unable to meet effluent nitrogen requirements with an additional constant risk of encouraging filament growth. A novel screening method based on special sampling campaigns for estimating carbon availability and C:N ratios of influent wastewater streams coming separately from the large catchment area, was developed and applied. Staging of the previously low DO basins into a flexible system containing non-aerated selectors proved to be efficient for enhancing both biological nitrogen removal and sculpturing appropriately settling biomass.
\end{abstract}

Keywords

activated sludge, carbon source availability, wastewater co-treatment, mathematical modelling, estimation of industrial influent

\section{Introduction}

Influents of Hungarian domestic wastewater treatment plants (WWTPs) are generally poor in readily biodegradable organic carbon source. However, depending on local water consumption practice, in retention time in sewer network as well as possible additional industrial discharge, remarkable differences can be measured from site to site $[1,2]$. Although low dissolved oxygen (low DO) environment may be favorable for cost-effective removal of nitrogen [3], it may lead to performance deterioration $[4,5]$ and cause enhanced $\mathrm{N}_{2} \mathrm{O}$ emission as well [6]. Additionally, low substrate (low S) concentration and/or low DO conditions may also increase the risk of excessive growth of filaments resulted in poor biomass settleability [7, 8]. In numerous cases, efficient biological nitrogen removal cannot be achieved without external organic carbon source dosing also by further use of liquid wastes for denitrification [9-12]. Carbon shortage of domestic influent wastewater has been becoming a global challenge in the last decade [2, 13-18]. Therefore, the cost-effective new technology of applying floating seals for excluding undesired oxygen penetration from non-aerated selectors $[8,19]$ is required as well as the further use of nutrients in agriculture is encouraged [20] for sustainable wastewater treatment and source recovery. At regional WWTPs with large catchment areas huge fluctuations may happen in influent quantity and quality including influent $\mathrm{C}: \mathrm{N}$ ratios $[2,21]$, especially when industrial wastewater flows are also discharged into the municipal sewer network [22]. Food-industrial wastewater streams are generally readily biodegradable, however, their $\mathrm{C}: \mathrm{N}$ ratios may be very different depending on the types of industry. Several kinds of food-industrial wastewaters (i.e. deriving from wineries, fruit juice, soft drink and beverage productions, etc.) may be severely nutrient deficient. In these cases, besides the remarkable operational costs, external nutrient dosing may have several 
risks and uncertainties [23]. Therefore, advanced technologies could be preferred, such as the pioneering development and application for encouraging growth of GAOs (Glycogen Accumulating Organisms) as cost-effective solution [24-26]. In wastewater treatment plants, receiving both carbon deficient municipal and carbon-rich (but nutrient deficient) food-industrial discharges from heterogeneous catchment areas, co-treatment of these influents may be a powerful solution resulting in higher denitrification capacity [22, 27-29] as well as other innovative co-treatment solutions may also lead to cost-effective operation [30,31].

Case study carried out at a Hungarian, regional municipal activated sludge WWTP operated at low DO conditions and receiving seasonally high carbon content wastewater from fruit juice industry (DOM\&IND-WWTP, hydraulic capacity: $1100 \mathrm{~m}^{3} \mathrm{~d}^{-1}$ ) aimed to upgrade biological nitrogen removal and decrease the risk of filamentous bulking as well. The quality and quantity of diverse wastewater streams collected from the large and heterogeneous catchment areas were not appropriately known. Due to the high hydraulic retention time (HRT $\sim 1.5 \mathrm{~d}$ ) in the activated sludge (AS) basins, industrial influent was noticed mainly by delayed detection of remarkable changes in plant performance. Therefore, the project for upgrading required the development of an appropriate methodology for detecting and quantifying the incoming industrial load as well as exploring and characterizing the diverse influent wastewater streams.

\section{Investigated full-scale system and research concept}

The original activated sludge wastewater treatment technology of the DOM\&IND-WWTP consisted of four aeration basins connected in parallel as illustrated in Fig. 1. Dissolved oxygen (DO) concentration in the bioreactors was maintained below $1 \mathrm{mg} \mathrm{L}^{-1}$, typically in the range of $0.1-0.5 \mathrm{mg} \mathrm{DO} \mathrm{L}^{-1}$ in order to ensure simultaneous nitrification and denitrification. The plant receives domestic wastewater transported through a short sewer system (from the city nearby), and an additional part of domestic wastewater streams coming from higher distances $(15-20 \mathrm{~km})$ of two agglomeration zones as well as seasonal industrial discharge of the fruit juice factory situated closer to the city. The mixed influent load had high fluctuations resulted in a broad influent quality and quantity spectrum.

The fully aerobic, but low DO system was unable to meet the effluent criteria $\left(\mathrm{NH}_{4} \mathrm{~N} 5 \mathrm{mg} \mathrm{L}^{-1}, \mathrm{TN} 30 \mathrm{mg} \mathrm{L}^{-1}\right)$ at the relatively high Mixed Liquor Suspended Solids (MLSS) concentration of $5 \mathrm{~g} \mathrm{~L}^{-1}$ applied, since depending on the inlet load either nitrification or denitrification failed. At the same time,

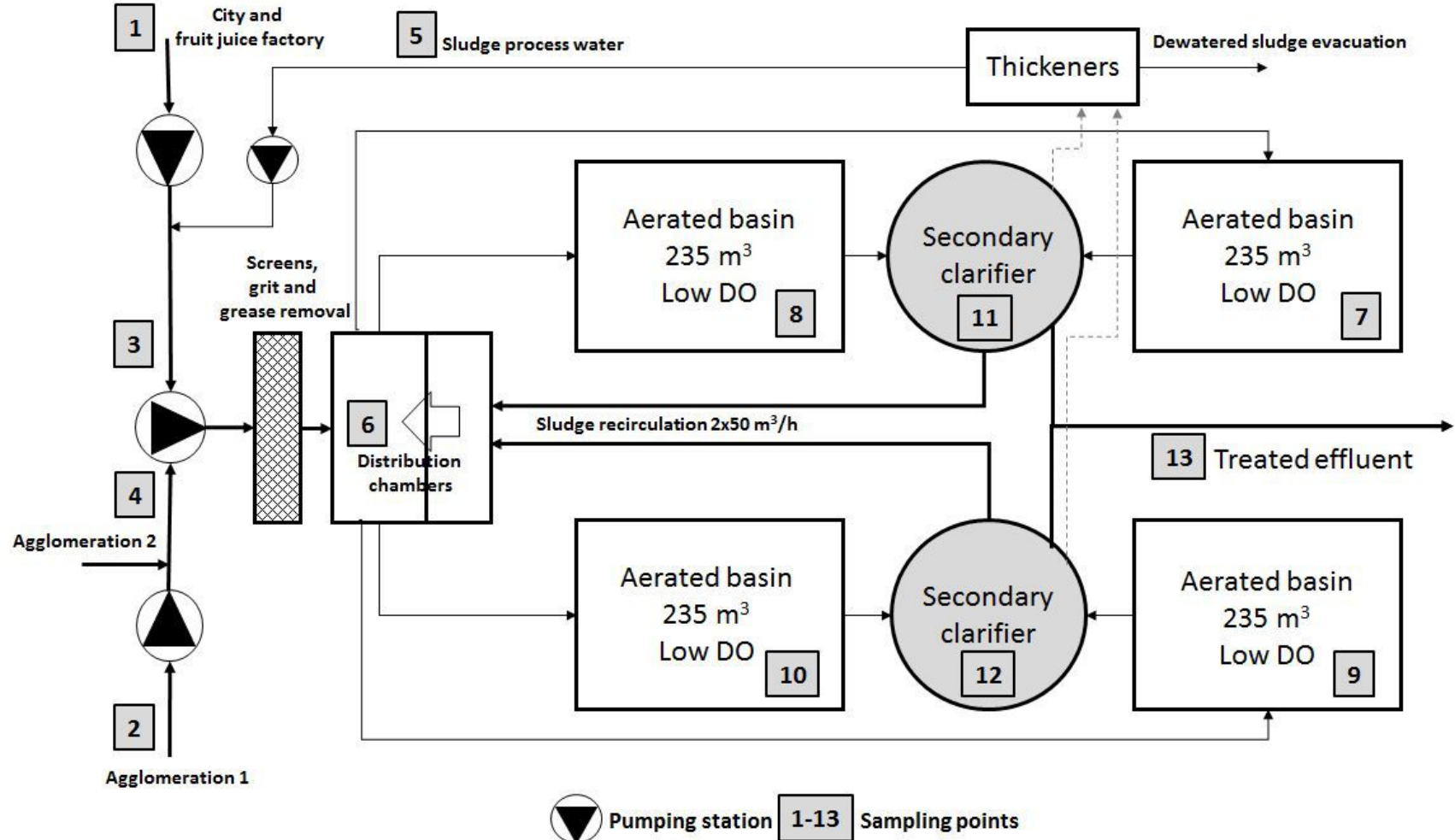

Fig. 1 Technological layout of the DOM\&IND-WWTP with the indication of sampling points (see black numbers on grey labels) chosen for on-site concentration profile measurements. 
periodically serious AS settleability problems occurred due to high filamentous abundance.

The upgrading concept aimed to transform the CSTR (Completely Stirred Tank Reactor) like, low-DO system into an appropriately staged, flexible technology through evaluation of operational data and careful investigation of incoming wastewater streams using on-site measurements and mathematical modelling.

\section{Materials and methods}

The operational and analytical data (temperature, Sludge Volume Index -SVI, Mixed Liquor Suspended Solids - MLSS, inlet and outlet parameters: $\mathrm{pH}$, Chemical Oxygen Demand - COD, five-day Biochemical Oxygen Demand - $\mathrm{BOD}_{5}$, Total Suspended Solids - TSS, Total Organic Carbon - TOC, Dissolved Organic Carbon - DOC, Total Kjeldahl Nitrogen - TKN, $\mathrm{NH}_{4} \mathrm{~N}, \mathrm{NO}_{2} \mathrm{~N}, \mathrm{NO}_{3} \mathrm{~N}$ and Total Phosphorus - TP concentrations) of the previous 3 years were carefully evaluated and discussed with the operator in order to explore former operational nuisances and their possible causes.

On-site concentration profile measurements were carried out both on the sewer network and at the WWTP (see Fig. 1) four times, during the period from March to August (i.e. March $9^{\text {th }}$, March $21^{\text {st }}$, June $14^{\text {th }}$ and August $\left.7^{\text {th }}\right)$. On each selected day of sampling four campaigns were carried out at all sampling points shifted in time consecutively (i.e. early morning, late morning, early afternoon and evening). Temperature, SVI, bioreactor DO concentration profile and MLSS as well as inlet and outlet $\mathrm{pH}, \mathrm{COD}$, dissolved COD, $\mathrm{BOD}_{5}$, TSS, TOC, DOC, $\mathrm{NH}_{4} \mathrm{~N}, \mathrm{NO}_{2} \mathrm{~N}, \mathrm{NO}_{3} \mathrm{~N}, \mathrm{TKN}$, dissolved TKN, $\mathrm{PO}_{4} \mathrm{P}$ and TP concentrations were measured. For determining dissolved parameters samples were centrifuged (12 $000 \mathrm{rpm}, 5 \mathrm{~min}$ ) and filtered through filter membrane (pore size: $0.45 \mu \mathrm{m}$ ), then analysis was carried out from the filtrate. AS samples were investigated under microscope (Olympus CX41) on each sampling day. Dissolved oxygen (DO) concentration and $\mathrm{pH}$ were measured by a portable WTW Multi 350i meter (WTW GmbH, Weilheim, Germany), for $\mathrm{BOD}_{5}$ manometric method and WTW OxiTop Control System was applied (WTW GmbH, Weilheim, Germany). Generally, the parameters were measured
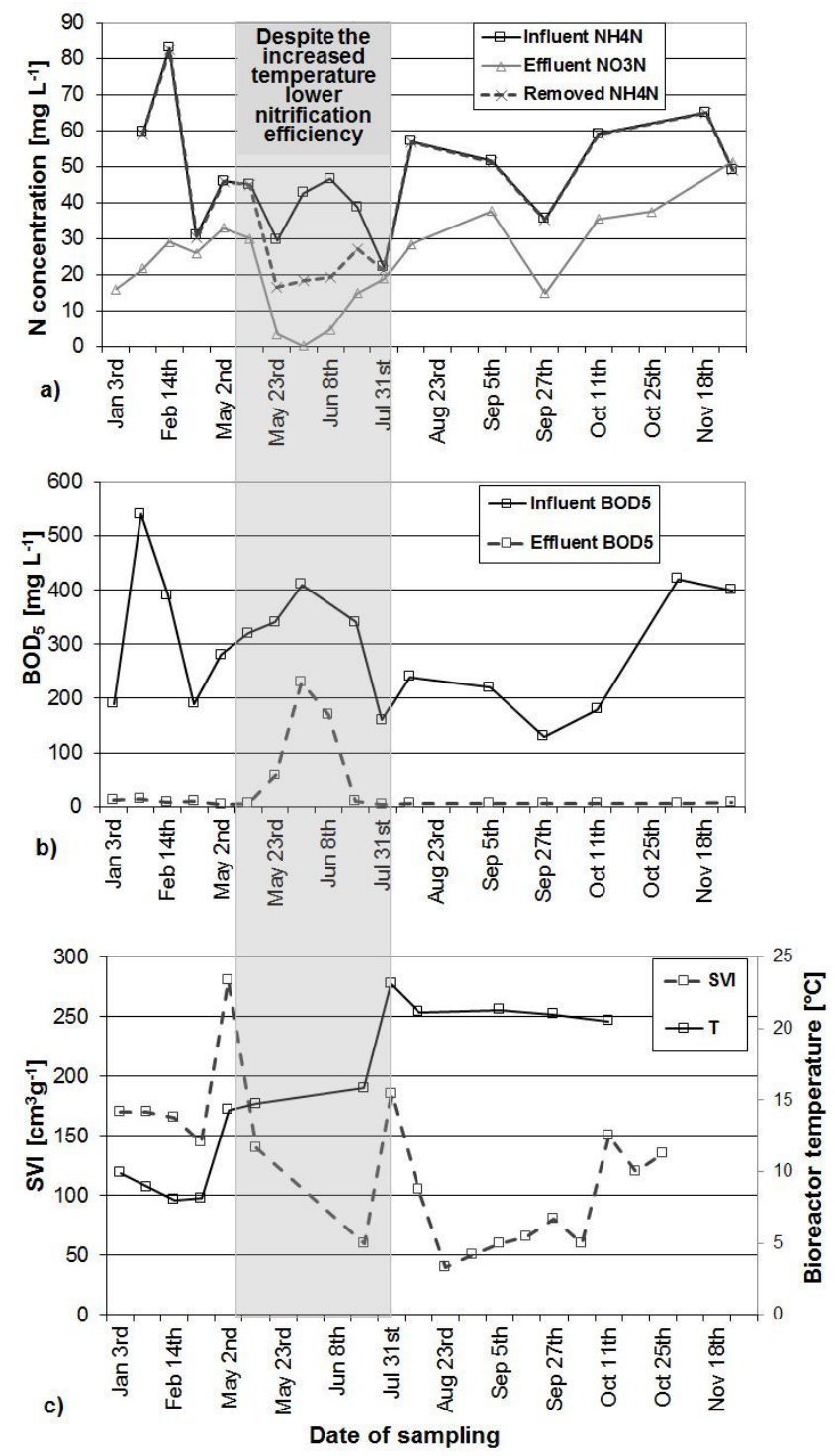

Fig. 2 Evaluated plant data measured by the operator preceding the on-site measurements.

according to the Hungarian Standards which matches international protocols [32]. For bio-kinetic calculations ASM1 (Activated Sludge Model 1) based SSSP [33] and ASM2d based BioWin 4.1 [34] softwares were used.

\section{Results and discussion}

As it is illustrated in Fig. 2 evaluation of plant data showed that nitrification efficiency dropped significantly

Table 1 Average wastewater quality of different influent streams coming from the different sewer trains and entering DOM\&IND-WWTP on March $9^{\text {th }}$ (Diss. = dissolved; Tot. = total; \pm values denote the standard deviation).

\begin{tabular}{cccccc}
\hline $\begin{array}{c}\text { Parameters/ } \\
\text { Wastewater origin }\end{array}$ & $\mathrm{T}$ & COD & Diss. COD & $\begin{array}{c}\text { Diss. COD / } \\
\text { Tot. COD ratio } \\
{[\%]}\end{array}$ & $\begin{array}{c}\text { Diss. TN } \\
\text { TN ratio } \\
{[-]}\end{array}$ \\
\hline $\begin{array}{c}\text { Short sewer (city and } \\
\text { fruit juice factory) } \\
\begin{array}{c}\text { Long sewer (urban } \\
\text { agglomeration) }\end{array}\end{array}$ & $16.9 \pm 1.5$ & $795 \pm 70$ & $558 \pm 29$ & $70 \pm 4.8$ & $48.0 \pm 8.8$ \\
\hline $\left.\mathrm{mg} \mathrm{L}^{-1}\right]$ & $10.1 \pm 0.4$ & $338 \pm 55$ & $118 \pm 23$ & $35 \pm 3.9$ & $91.1 \pm 13.1$ \\
\hline
\end{tabular}


down (see Fig. 2 (a)) in accordance with increased influent organic load (see Fig 2 (b)) even in the indicated range when bioreactor temperature was increasing. It can be assumed that during this period dissolved oxygen (DO) concentration decreased due to the increasing organic load and decreasing solubility of oxygen.

At the same time, increased denitrification efficiency can be observed (see Fig. 2 (a)) in accordance with the assumed low DO conditions and the high availability of carbon source (see Fig. 2 (b)). Nevertheless, as it is shown in Fig. 2 (c) SVI level could not be reliably stabilized below $150 \mathrm{~cm}^{3} \mathrm{~g}^{-1}$ except for chemical dosing the data refer to. On the other hand, in the cold period (from January through early May) there could be full nitrification and carbon removal whereas decreased denitrification efficiency detected, most probably, due to an increased DO level.

Through evaluation of plant data the causes of treatment nuisances could not be clearly explored and neither the responsible process failures nor the influencing influent wastewater streams could be satisfactorily identified.

On-site measurements showed huge differences regarding the quality of the diverse incoming wastewater streams (see Table 1). Although the mixed wastewater of the city and the fruit juice factory proved to be appropriate for efficient denitrification, the wastewater of the distant agglomeration zones proved to be severely carbon deficient.

Although the on-site measurements provided a detailed screening of the diverse incoming wastewater streams, additional background information received from the operator about the industrial discharge around the sampling days was rather uncertain, and inflows coming by night or suddenly as shock-load could not be detected either. Regarding these uncertainties and taking also into account the high HRT ( 1.5 d) in the AS basins, on-site profile measurements did not prove to be satisfactory for fitting the measured effluent concentrations to an appropriate influent quality. The only reliable information was that there was no industrial discharge before the sampling on August $7^{\text {th }}$ (last sampling day of the campaign) due to the production stoppage of the fruit juice factory. However, the rate of industrial discharge was unknown for the other three dates of the campaign.

For developing a good estimation, the typical characteristics of different domestic wastewater streams were determined based on the concentration profile measurement data detected on August $7^{\text {th }}$. Then, further calculations were carried out applying mixing equations in order to estimate the industrial wastewater quality with the use of data acquired during the previous sampling days. Finally, a wastewater load spectrum (both for quality and relatable quantity) was built up for finding the one entering the plant most likely (see Table 2 and Fig. 3).

In order to identify the industrial fraction in the mixed influents of the first three sampling days (March $9^{\text {th }}$, March $21^{\text {st }}$, and June $14^{\text {th }}$ ), a new method was developed and applied for influent wastewater characterization including both on-site concentration profile measurements and application of ASM modelling. Mathematical simulation characterizing the low DO system was carried out for the whole wastewater loading spectrum determined previously on the basis of analytical and influent flow data (see Table 2 and Fig. 3) as well as the technological and design data presented in Fig. 1. Fig. 4 illustrates the curves of the calculated effluent $\mathrm{NO}_{3} \mathrm{~N}$ concentrations in case of different influent wastewater qualities investigated. The detected effluent nitrate concentrations are indicated by large rectangular filled black markers on the diagram of Fig. 4. Data of August $7^{\text {th }}$ were used as

Table 2 Characterization of potentially occurring mixed influent wastewater streams entering the plant regarding the flow rates presented in Fig. 3.

\begin{tabular}{|c|c|c|c|c|c|c|c|c|}
\hline & \multicolumn{7}{|c|}{ Parameter } & \multirow{3}{*}{$\begin{array}{c}\text { Biodegradable } \\
\text { carbon } \\
\text { availability }\end{array}$} \\
\hline & Tot. COD & Diss. COD & $\begin{array}{l}\text { Diss. COD / } \\
\text { Tot COD }\end{array}$ & TN & Diss. TN & $\mathrm{NH}_{4} \mathrm{~N}$ & $\begin{array}{l}\text { Diss. COD / } \\
\text { Diss. TN }\end{array}$ & \\
\hline & {$\left[\mathrm{mg} \mathrm{L}^{-1}\right]$} & {$\left[\mathrm{mg} \mathrm{L}^{-1}\right]$} & {$[\%]$} & {$\left[\mathrm{mg} \mathrm{L}^{-1}\right]$} & {$\left[\mathrm{mg} \mathrm{L}^{-1}\right]$} & {$\left[\mathrm{mg} \mathrm{L}^{-1}\right]$} & {$[-]$} & \\
\hline $\begin{array}{l}\text { Purely domestic without } \\
\text { industrial fraction }\end{array}$ & 551 & 260 & 47 & 90 & 80 & 70 & 3.3 & Poor \\
\hline $\begin{array}{c}\text { Domestic }+ \text { low industrial } \\
\text { discharge }\end{array}$ & 621 & 345 & 56 & 87 & 78 & 68 & 4.4 & Marginal \\
\hline $\begin{array}{l}\text { Domestic }+ \text { moderate } \\
\text { industrial discharge }\end{array}$ & 737 & 489 & 66 & 83 & 75 & 64 & 6.5 & Good \\
\hline $\begin{array}{c}\text { Domestic }+ \text { full industrial } \\
\text { discharge }\end{array}$ & 802 & 569 & 71 & 80 & 73 & 62 & 7.8 & Good \\
\hline $\begin{array}{l}\text { Domestic }+ \text { increased } \\
\text { industrial discharge }\end{array}$ & 938 & 735 & 78 & 75 & 69 & 57 & 10.7 & Excellent \\
\hline
\end{tabular}


- Fruit juice factory

nomestic (Agglomeration area 2)

Domestic (Agglomeration area 1)

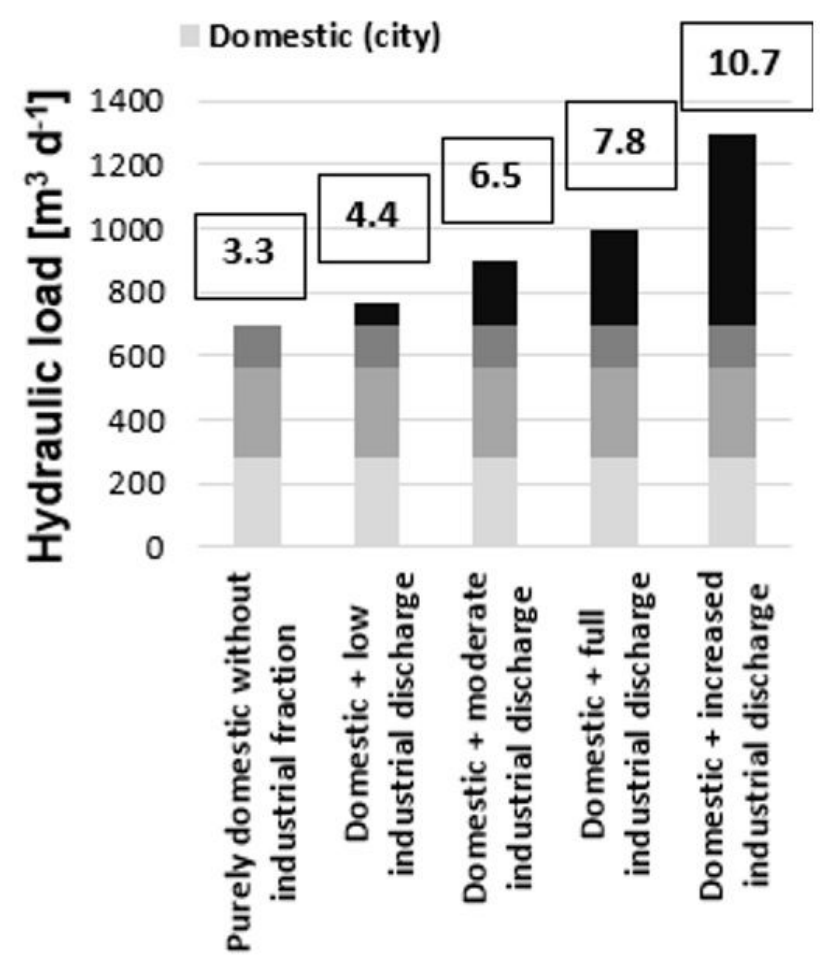

Fig. 3 Potentially occurring flow portions of the mixed influent hydraulic load (different dissolved COD / dissolved TN ratios are indicated on the top of the columns of the diagram, changing between 3.3 and 10.7).

a reference for model fitting as there was no industrial influent in that period due to production break in the fruit juice factory. (The same calculations were carried out for effluent $\mathrm{NH}_{4} \mathrm{~N}$ concentrations as well.) Good estimations for targeting influent industrial wastewater fraction of the first three sampling days could be carried out through the comparison of the calculated nitrate concentrations (curves) and the measured effluent values (large rectangular filled black markers).

The mathematical simulation study confirmed the hypothesis that the original, low DO system is not able to fulfill the effluent requirements, neither in case of lacking or low industrial influent (leading to high effluent nitrate) nor in case of high industrial discharge (due to deterioration of nitrification at lower temperatures).

Therefore, a flexible, staged bioreactor arrangement containing separated anoxic and aerated basins was proposed instead of the previously operated fully aerated, CSTR-like low DO system as illustrated in Fig. 5. Aerated low DO basins were reconfigured into tanks in series, and one of them was staged for an anoxic and an alternatively operated anoxic and aerobic basin at the head of the AS system. While in case of lacking or low industrial influent anoxic mode was recommended for the alternative bioreactor, at higher industrial discharge aeration was proposed. In the aerated bioreactors DO concentration was suggested to set high enough (up to $\sim 2 \mathrm{mg} \mathrm{L}^{-1}$ ) for efficient nitrification in the reduced, aerated volume. Possibility of internal nitrate recirculation was added in order to enhance pre-denitrification depending on inlet carbon source availability.

The calculated effluent ammonium concentrations of the staged system showed full nitrification in the investigated temperature and influent load ranges as illustrated in Fig. 6. The reduced aerated volume (with decreased aerobic SRT - Sludge Retention Time) was, however, operated at the higher DO level and thereby proved to be enough for efficient ammonium oxidation. The effluent ammonium concentration increased above $1 \mathrm{mg} \mathrm{NH}_{4} \mathrm{~N} \mathrm{~L}^{-1}$ only in case of increased industrial discharge at $12{ }^{\circ} \mathrm{C}$ but remained under $3 \mathrm{mg} \mathrm{NH}_{4} \mathrm{~N} \mathrm{~L}^{-1}$ without any risk of exceeding the limit value of $5 \mathrm{mg} \mathrm{NH}_{4} \mathrm{~N} \mathrm{~L}^{-1}$.

In case of industrial inflow effluent nitrate concentration could be safely maintained under $20 \mathrm{mg} \mathrm{NO}_{3} \mathrm{~N} \mathrm{~L}^{-1}$ (see Fig. 7), however, without industrial discharge effluent concentrations were typically in the range of $22-27 \mathrm{mg}$ $\mathrm{NO}_{3} \mathrm{~N} \mathrm{~L}^{-1}$ referring to the poor readily biodegradable carbon source availability of the mixed, purely domestic wastewater. These results verified that the industrial load coming as the discharge of the fruit juice factory has beneficial effect on the influent $\mathrm{C}: \mathrm{N}$ ratio, leading to enhanced denitrification efficiency.

However, in the absence of industrial discharge, the effluent TN may go up close to the limit value of $30 \mathrm{mg} \mathrm{TN} \mathrm{L}^{-1}$ (see Fig. 8) and external carbon dosing may be necessary for matching safely the effluent limit criteria. Results are in good accordance with earlier studies on co-treatment of domestic and diary wastewater [21].

The new, staged and flexible configuration developed by onsite measurements and mathematical simulation for the originally CSTR-like system enabled to meet the effluent nitrogen criteria for the whole investigated inlet wastewater load spectrum in the bioreactor temperature range of $12-26{ }^{\circ} \mathrm{C}$ without external carbon source dosing and bioreactor volume extension. Calculations were carried out for estimating the achievable operation cost savings by the use of food-industrial wastewater for cost-effective co-treatment instead of dosing commercial external carbon source for denitrification. In case of treating purely 


\section{CURVES AND RELATED SMALL DATA MARKERS: SEPARATE LARGE FILled RECTANGULAR BLACK} calculated effluent $\mathrm{NO}_{3} \mathrm{~N}$ concentrations for the possible inlet quality and temperature range

MARKERS: measured effluent $\mathrm{NO}_{3} \mathrm{~N}$ concentrations

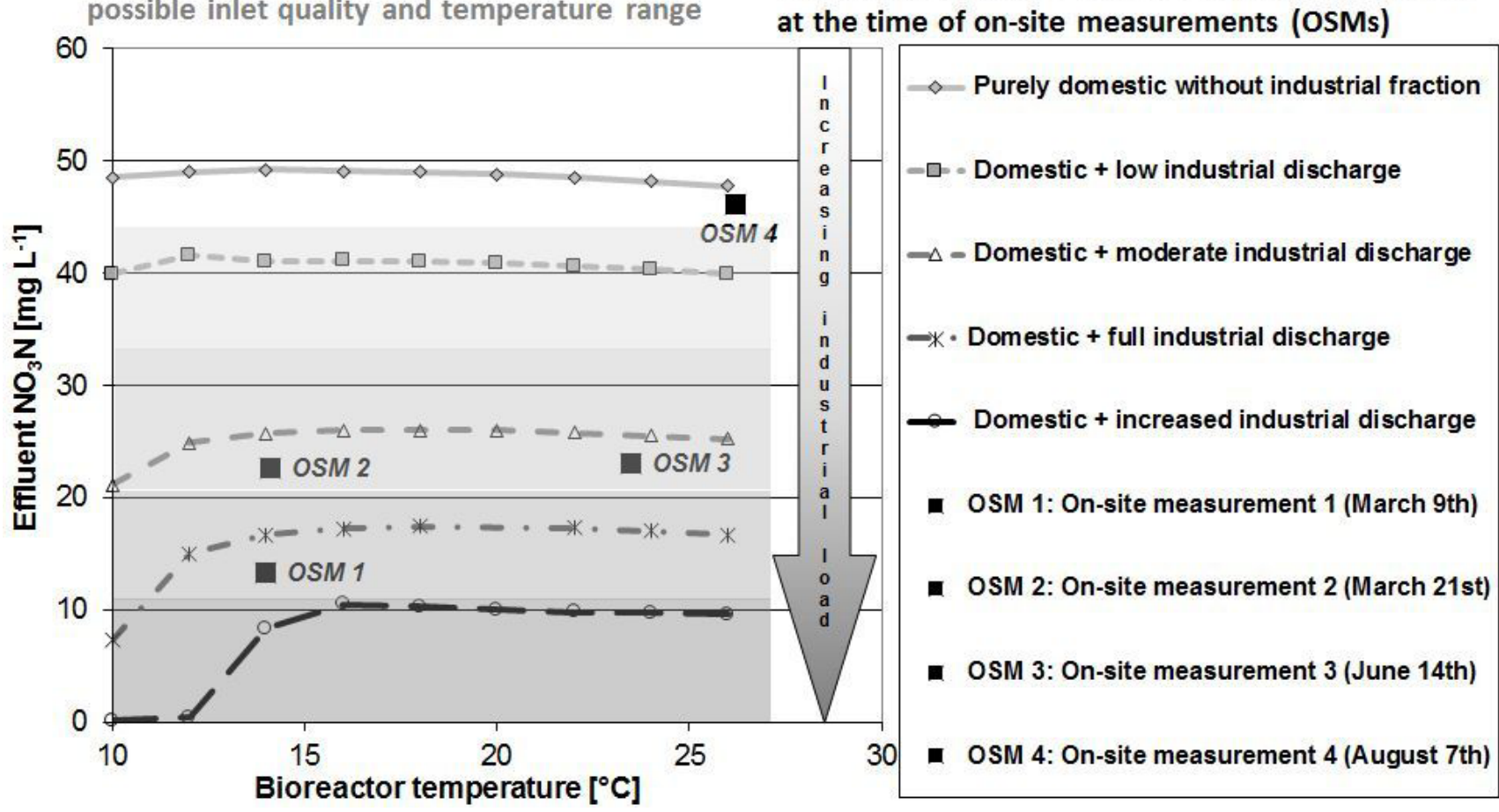

Fig. 4 Measured (large rectangular filled black markers) and calculated (curves and related small data markers) effluent nitrate concentrations at different inlet loads with different amounts of industrial discharge.

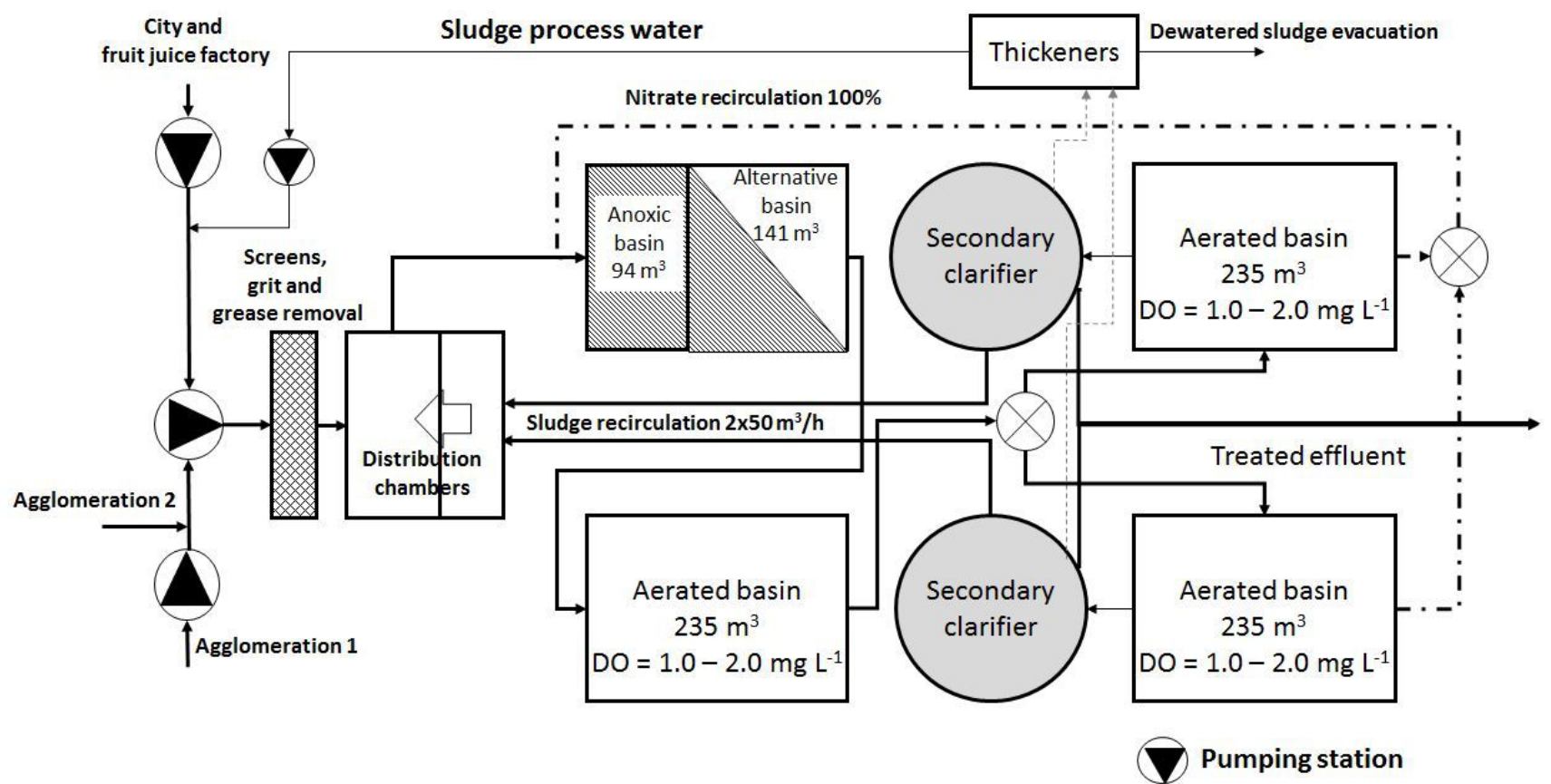

Fig. 5 Technological layout of the upgraded (staged and flexible) system. 


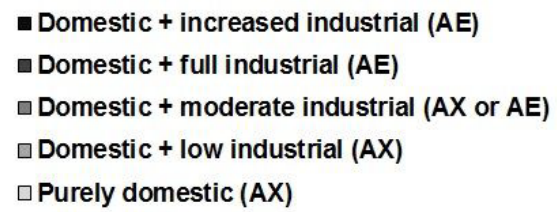

(AX): alternative basin operated in non-aerated mode $(\mathrm{AE})$ : alternative basin operated in aerated mode

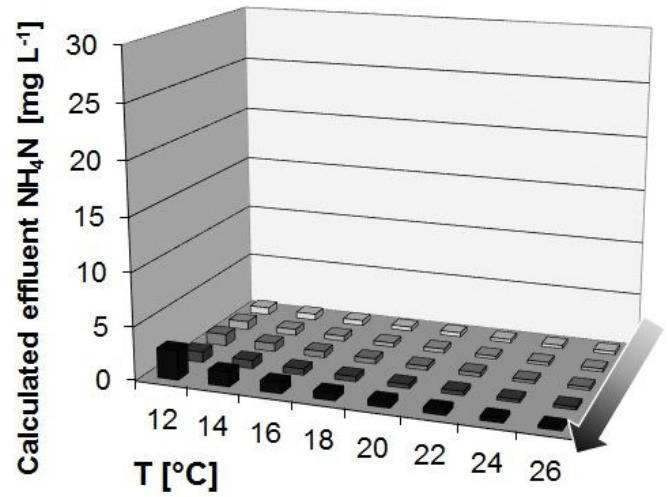

Fig. 6 Simulation results for effluent $\mathrm{NH}_{4} \mathrm{~N}$ concentrations in case of staged bioreactor arrangement, including anoxic and aerobic basins.



$(A X)$ : alternative basin operated in non-aerated mode

$(\mathrm{AE})$ : alternative basin operated in aerated mode

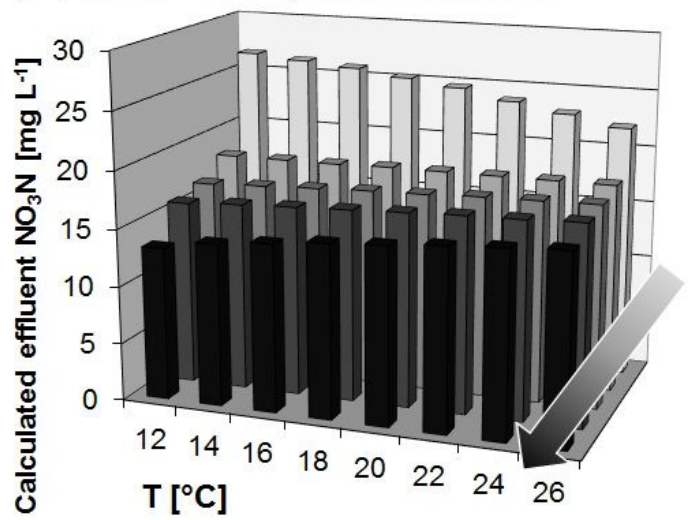

Fig. 7 Simulation results for effluent $\mathrm{NO}_{3} \mathrm{~N}$ concentrations in case of staged bioreactor arrangement, including anoxic and aerobic basins.

readily biodegradable carbon deficient domestic wastewater the necessary external carbon source dosing would be approx. $93 \mathrm{~kg}$ methanol $\mathrm{d}^{-1}$ at an average incoming domestic wastewater flow rate of $700 \mathrm{~m}^{3} \mathrm{~d}^{-1}$ for achieving an influent $\mathrm{C} / \mathrm{N}$ ratio appropriate for efficient denitrification (as in case of Domestic + moderate industrial discharge wastewater quality in Table 2). At the current price of approx. $0.54 \mathrm{EUR} \mathrm{kg}^{-1}$ methanol available for industrial

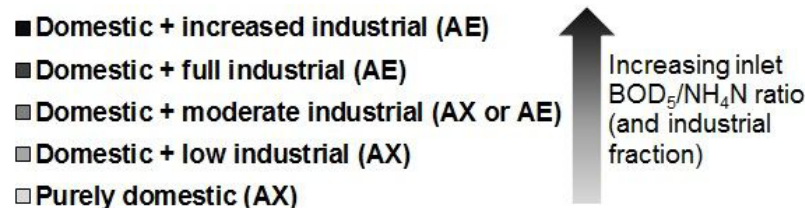

$(A X)$ : alternative basin operated in non-aerated mode

$(\mathrm{AE})$ : alternative basin operated in aerated mode

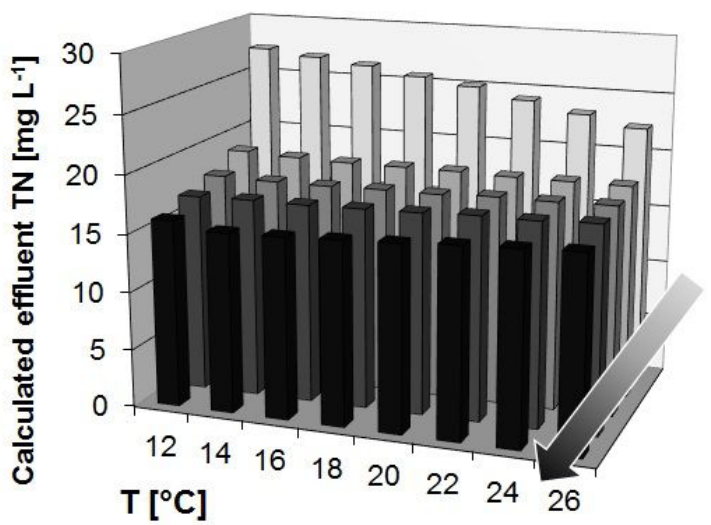

Fig. 8 Simulation results for effluent TN concentrations in case of staged bioreactor arrangement, including anoxic and aerobic basins.

use in Hungary, the estimated additional yearly opera-

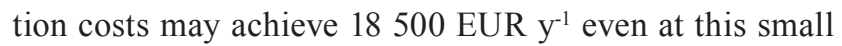
regional WWTP. On the basis of the onsite study a basically similar, flexible and staged system was implemented in the full-scale system that could efficiently control the growth of filaments as well.

\section{Conclusions and major findings}

For state of the art design and upgrading of WWTPs the plant and its catchment area should be considered as an integrated system, particularly in case of combined treatment of domestic and industrial discharges.

In the case study of a domestic activated sludge wastewater treatment plant receiving high carbon content wastewater of a fruit juice factory seasonally, a novel method has been developed for revealing inlet wastewater quality through combining on-site measurements with mathematical simulation. This new methodology can be applied for detecting occasional and/or seasonal influent loads of industrial origin, estimating the quantity of incoming industrial discharge, and discovering latent industrial (shock-)loads as well.

In case of highly fluctuating inlet quality, staged bioreactor arrangement and possibility of flexible operation proved to be much more efficient than the original un-staged, low $\mathrm{S}$ - low DO system aiming simultaneous nitrification and denitrification. Besides meeting the effluent nitrogen 
criteria the new bioreactor arrangement proved to be able to minimize the risk of filamentous bulking.

Application of appropriately staged bioreactor arrangement resulted in efficient carbon consumption coupled with enhanced biological nitrogen removal and facilitated good biomass settleability. The novel detection and quantification method for estimating influent industrial load and the proposed co-treatment technology in staged bioreactors proved to be cost-effective for replacing external carbon source dosing and saving remarkable additional operational expenses.

\section{References}

[1] Makinia, J. "Mathematical modelling and computer simulation of activated sludge systems", IWA Publishing, London, UK, 2010.

[2] Tardy, G. M., Bakos, V., Jobbágy, A. "Conditions and technologies of biological wastewater treatment in Hungary", Water Science \& Technology, 65(9), pp. 1676-1683, 2012. https://doi.org/10.2166/wst.2012.062

[3] Guo, J., Peng, Y., Wang, S., Zheng, Y., Huang, H., Wang, Z. "Long-term effect of dissolved oxygen on partial nitrification performance and microbial community structure", Bioresource Technology, 100(11), pp. 2796-2802, 2009. https://doi.org/10.1016/j.biortech.2008.12.036

[4] Jobbágy, A., Simon, J., Plósz, B. "The impact of oxygen penetration on the estimation of denitrification rates in anoxic processes", Water Research, 34(9), pp. 2606-2609, 2000. https://doi.org/10.1016/S0043-1354(00)00013-0

[5] Plósz, B. Gy., Jobbágy, A., Grady Jr., C. P. L. "Factors influencing deterioration of denitrification by oxygen entering an anoxic reactor trough the surface", Water Research, 37(4), pp. 853-863, 2003. https://doi.org/10.1016/S0043-1354(02)00445-1

[6] Kampschreur, M. J., Temmink, H., Kleerebezem, R., Jetten, M. S. M., van Loosdrecht, M. C. M. "Nitrous oxide emission during wastewater treatment", Water Research, 43(17), pp. 4093-4103, 2009. https://doi.org/10.1016/j.watres.2009.03.001

[7] Wanner, J., Jobbágy, A. "Activated sludge solids separations", In: Jenkins, D., Wanner, J. (eds.) Activated sludge - 100 years and counting, IWA Publishing, Glasgow, UK, 2014, pp. 171-194.

[8] Jobbágy, A., Weinpel, T., Bakos, V., Vánkos, Zs. "Factors potentially converting non-aerated selectors into 'low-S-low-DO basins', effects of seal-covering", In: 12th IWA Specialised Conference on Design, Operation and Economics of Large Wastewater Treatment Plants, Prague, Czech Republic, 2015, pp. 149-155.

[9] Czerwionka, K., Makinia, J., Kaszubowska, M., Majtacz, J., Angowski, M. "Distillery wastes as external carbon sources for denitrification in municipal wastewater treatment plants", Water Science \& Technology, 65(9), pp. 1583-1590, 2012.

https://doi.org/10.2166/wst.2012.050

\section{Acknowledgements}

The research was supported by Danube Bend Regional Waterworks Pte. Ltd. (Vác-Szob, Hungary) as well as by the Higher Education Excellence Program (FIKP) of the Ministry of Human Capacities (EMMI) within the frame of Biotechnology research area at Budapest University of Technology and Economics (BME FIKPBIO). Authors express their thanks to Kálmán Pécsi and Gusztáv Miklósfalvi for their valuable and supporting efforts during the whole project. Valuable technical help of Bernadett Lemaire in analytical measurements and microscopic observations is also highly acknowledged.

[10] Czerwionka, K., Luczkiewicz, A., Majtacz, J., Kowal, P., Jankowska, K., Ciesielski, S., Pagilla, K., Makinia, J. "Acclimation of denitrifying activated sludge to a single vs. complex external carbon source during a start-up of sequencing batch reactors treating ammonium-rich anaerobic sludge digester liquors", Biodegradation, 25(6), pp. 881-892, 2014. https://doi.org/10.1007/s10532-014-9707-0

[11] Swinarski, M., Makinia, J., Czerwionka, K., Chrzanowska, M., Drewnowski, J. "Comparison of the Effects of Conventional and Alternative External Carbon Sources on Enhancing the Denitrification Process", Water Environment Research, 81(9), pp. 896-906, 2009. https://doi.org/10.2175/106143009X407438

[12] Swinarski, M., Makinia, J., Stensel, H. D., Czerwionka, K., Drewnowski, J. "Modeling External Carbon Addition in Biological Nutrient Removal Processes with an Extension of the International Water Association Activated Sludge Model", Water Environment Research, 84(8), pp. 646-655, 2012. https://doi.org/10.2175/106143012X13373550426670

[13] Oleszkiewicz, J. A., Barnard, J. L. "Nutrient Removal Technology in North America and the European Union: A Review", Water Quality Research Journal, 41(4), pp. 449-462, 2006. https://doi.org/10.2166/wqrj.2006.048

[14] Somlyódy, L., Patziger, M. "Urban wastewater development in Central and Eastern Europe", Water Science \& Technology, 66(5), pp. 1081-1087, 2012. https://doi.org/10.2166/wst.2012.289

[15] Sun, Y., Chen, Z., Wu, G., Wu, Q., Zhang, F., Niu, Z., Hu, H. Y. "Characteristics of water quality of municipal wastewater treatment plants in China: implications for resources utilization and management", Journal of Cleaner Production, 131, pp. 1-9, 2016. https://doi.org/10.1016/j.jclepro.2016.05.068

[16] Patziger, M. "Efficiency and Development Strategies of Medium-Sized Wastewater Treatment Plants in Central and Eastern Europe: Results of a Long-Term Investigation Program in Hungary", Journal of Environmental Engineering, 143(6), Article Number: 04017008, 2017. https://doi.org/10.1061/(ASCE)EE.1943-7870.0001185 
[17] Drewnowski, J., Remiszewska-Skwarek, A., Fudala-Ksiazek, S., Luczkiewicz, A., Kumari, S., Bux, F. "The evaluation of COD fractionation and modeling as a key factor for appropriate optimization and monitoring of modern cost-effective activated sludge systems", Journal of Environmental Science and Health, Part A: Toxic/Hazardous Substances and Environmental Engineering, 54(8), pp. 736-744, 2019.

https://doi.org/10.1080/10934529.2019.1592531

[18] Cai, Y., Zaidi, A. A., Sun, P., Shi, Y., Zhang, K., Lin, A. "Effect of Volume Loading Rate and $\mathrm{C} / \mathrm{N}$ on Ship Domestic Sewage Treatment by Two Membrane Bioreactors", Periodica Polytechnica Chemical Engineering, 64(3), pp. 328-339, 2020.

https://doi.org/10.3311/PPch.14672

[19] Jobbágy, A., Weinpel, T., Bakos, V., Vánkos, Zs. "Use of floating seals to exclude oxygen penetration in non-aerated selectors", Water Science \& Technology, 80(2), pp. 357-364, 2019.

https://doi.org/10.2166/wst.2019.280

[20] Nagy, J., Mikola, A., Pradhan, S. K., Zseni, A. "The Utilization of Struvite Produced from Human Urine in Agriculture as a Natural Fertilizer: A Review", 63(3), pp. 478-484, 2019. https://doi.org/10.3311/PPch.12689

[21] Wang, H., Song, Q., Wang, J., Zhang, H., He, Q., Zhang, W., Song, J., Zhou, J., Li, H. "Simultaneous nitrification, denitrification and phosphorus removal in an aerobic granular sludge sequencing batch reactor with high dissolved oxygen: Effects of carbon to nitrogen ratios", Science of The Total Environment, 642, pp. 1145-1152, 2018. https://doi.org/10.1016/j.scitotenv.2018.06.081

[22] Weinpel, T., Bakos, V., Jobbágy, A. "Co-treatment of a Carbon Deficient Domestic Wastewater with a Dairy Process Effluent for a Cost-effective Global Solution", Periodica Polytechnica Chemical Engineering, 62(4), pp. 432-440, 2018. https://doi.org/10.3311/PPch.12856

[23] Bakos, V., Kiss, B., Jobbágy, A. "Problems and causes of marginal nutrient availability in winery wastewater treatment", Acta Alimentaria, 45(4), pp. 532-541, 2016. https://oi.org/10.1556/066.2016.45.4.10

[24] Jobbágy, A., Literáthy, B., Tardy, G. "Implementation of glycogen accumulating bacteria in treating nutrient-deficient wastewater", Water Science \& Technology, 46(1-2), pp. 185-190, 2002. https://doi.org/10.2166/wst.2002.0475
[25] Kiss, B., Bakos, V., Liu, W. T., Jobbágy, A. "Full-Scale Use of Glycogen-Accumulating Organisms for Excess Biological Carbon Removal", Water Environment Research, 83(9), pp. 855-864, 2011. https://doi.org/10.2175/106143010X12851009156844

[26] Jobbágy, A., Kiss, B., Bakos, V. "Conditions Favoring Proliferation of Glycogen Accumulating Organisms for Excess Biological Carbon Removal in Treating Nutrient Deficient Wastewater", Periodica Polytechnica Chemical Engineering, 61(3), pp. 149-155, 2017. https://doi.org/10.3311/PPch.10078

[27] Cappai, G., Carucci, A., Onnis, A. "Use of industrial wastewaters for the optimization and control of nitrogen removal processes", Water Science \& Technology, 50(6), pp. 17-24, 2004. https://doi.org/10.2166/wst.2004.0354

[28] De Lucas, A., Rodríguez, L., Villaseñor, J., Fernández, F. J. "Denitrification potential of industrial wastewaters", Water Research, 39(15), pp. 3715-3726, 2005. https://doi.org/10.1016/j.watres.2005.06.024

[29] Rodríguez, L., Villaseñor, J., Fernández, F. J. "Use of agro-food wastewaters for the optimisation of the denitrification process", Water Science \& Technology, 55(10), pp. 63-70, 2007. https://doi.org/10.2166/wst.2007.307

[30] Qian, J., Lu, H., Jiang, F., Ekama, G. A., Chen, G. H. "Beneficial co-treatment of simple wet flue gas desulphurization wastes with freshwater sewage through development of mixed denitrificationSANI process", 262, pp. 109-118, 2015. https://oi.org/10.1016/j.cej.2014.09.066

[31] Fudala-Ksiazek, S., Kulbat, E., Luczkiewicz, A "Nitrification, denitrification, and dephosphatation capability of activated sludge during co-treatment of intermediate-age landfill leachates with municipal wastewater", Environmental Technology, 39(8), pp. 986-996, 2018. https://doi.org/10.1080/09593330.2017.1317842

[32] American Public Health Association (APHA) "Standard Methods for the Examination of Water and Wastewater", American Public Health Association, Washington, DC, USA, 1999.

[33] Henze, M., Grady, Jr., C. P. L., Gujer, W., Marais, G. V. R., Matsuo, T. "A general model for single-sludge wastewater treatment systems", Water Research, 21(5), pp. 505-515, 1987. https://oi.org/10.1016/0043-1354(87)90058-3

[34] EnviroSim Associates Ltd. "Envirosim 2007 BioWin 4.1 Process Simulator" [computer program] Available at: https://envirosim.com/ [Accessed: 19 May 2019] 